
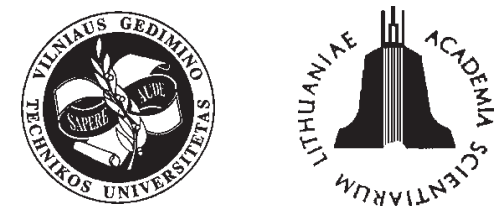

ISSN 1392-3730 print / ISSN 1822-3605 online

JOURNAL OF CIVIL ENGINEERING AND MANAGEMENT

http:/www.jcem.vgtu.lt

2006, Vol XII, No 1, 29-36

\title{
COMBINED HEAT AND POWER PRODUCTION: SOCIO-ECONOMIC AND SUSTAINABLE DEVELOPMENT ASPECTS
}

\author{
Nerijus Rasburskis, Juozas Gudzinskas, Jonas Gylys \\ Dept of Thermal and Nuclear Energy, Kaunas University of Technology, \\ K. Donelaičio g. 20,.LT-44239, Kaunas,Lithuania.E-mail: nerijus.rasburskis@stud.ktu.lt
}

Received 13 May 2005; accepted 13 Dec 2005

\begin{abstract}
The paper is based on the study of Lithuania facing the need for huge investments in both the replacement of the Ignalina nuclear power station and the replacement of district heating production units in many of the existing systems. Lithuania has a big technical potential for implementing small-scale combined heat and power production (CHP) systems. Meanwhile, such implementation needs public regulation to become feasible not only from a socioeconomic, but also from a business economic point of view. The study focuses upon the analysis of methods for the incorporation of technical, economical and environmental considerations into large-scale investment decision-making in the energy sector. The research study could be a guideline for determination of national potential for high efficiency CHP not only from the technical, but both the economical and the environmental point of view. Based upon the results of the study investigation and analysis, areas for improvement in current energy sector investment decision-making processes are highlighted, and areas for further research are recommended.
\end{abstract}

Keywords: Lithuania, sustainable development, energy sector, combined heat and power production (CHP), district heating $(\mathrm{DH})$, decision-making process.

\section{Introduction}

The term "sustainable development" was conceptualised and first came into documented use during the preparation of the World Conservation Strategy, in 1980 [1]. The sustainable energy debate encompasses a wide range of issues, and demands the participation and involvement of various players at the local, national and international levels. Hence, sustainable development and reliability are the major energy policy objectives in the European Union (EU). The EU guidelines in the electricity generation stage are characterised by replacing the energy systems, which are based on large power plants with more decentralised systems. The goal is to double the CHP production in the EU from $9 \%$ in 1994 to $18 \%$ in 2010 [2]. In general, the implementation of CHP has the potential of reducing fuel consumptions by $20-30 \%$ in comparison with condensing power plants and heat only boilers (conventional energy production) and at the same time producing exactly the same amount of heat and electricity [3].

In Lithuania approx $45 \%$ of households are connected to district heating $(\mathrm{DH})$ systems, which is approx $60 \%$ of the national heat demand in accordance to final consumption [4]. Meanwhile, the share of small scale CHP is very small as the main electricity supply comes from relatively cheap nuclear power (NP) providing approx $80 \%$ of the national demand. However, the existing Ignalina Nuclear Power Plant (NPP) is to be decommissioned by 2010, and consequently the conventional condensing plant "Lietuvos Elektrine" (LE) with a total capacity of $1800 \mathrm{MW}_{\mathrm{el}}$ is expected to be the main production unit. LE currently operates on three types of fuel: natural gas, heavy fuel oil and orimulsion. Without NPP, the Lithuanian energy system will have a substantial fuel saving potential by implementing CHP technologies. Thus, the revised National Energy Strategy (NES) in 2002 stresses the promotion of CHP technologies in the DH sector [5]. However, the optimal CHP capacities in order to ensure sustainable and reliable energy generation are still very uncertain.

The decision-making process of how to replace the electricity production from the existing nuclear power plant after 2009 is still open. New or reconstructed NPP is expected to have long-term marginal costs (LTMC), which are almost by $60-80 \%$ higher than the current ones. This places NP on a comparable level with large condensing combined cycle gas turbine (CCGT) production [6]. Hence, even with the uncertainty regarding the future of NP, the feasibility of small scale CHP should be compared with centralised-conventional electricity generation.

Lithuania has very limited amounts of primary fuel resources and relies on imports, mainly from Russia. In 
the early 1990's, an energy crisis occurred, when Russia imposed an embargo on natural gas and oil supplies to Lithuania. This experience showed that decreasing fuel consumption can give not only positive effect on national balance of payments, but it can also improve the security of energy supply.

Traditional investment financial analysis is very often based on several basic approaches and techniques, using calculations of net present value (NPV), internal rate of return (IRR) and simple payback period. These methods using cash flows and discounting calculations are relatively simple, taking into account only a few inputs (cash flows, discount rate, time and usually limited number of costs). However, problems with holistic approach of analysis include missing information on whether the systems have environmental impacts or not, and the possible effects of mitigating environmental impacts (emissions, wastes etc).

Life cycle assessment methods (EDIP, Ecoindicator 99, CML) and tools (SimaPRO6, REGIS, TEAM ${ }^{\text {TM }} 3.0$ ) were originally developed for decision-making related to product development, but they can be successfully used as a tool for better understanding the potential impacts of more or less any activity, including investment in a new venture. Life cycle assessment (LCA) takes into account the "cradle to grave" impact of activities, and shows a summed environmental burden of the analysed activity. Ideally, in decision-making LCA methods should be directly linked to environmental risk methods and support them with essential data.

Based on the Lithuanian case, this paper analyses the experience of integrating small scale CHP into the existing energy system as compared to conventional electricity generation using not only the technical and the economical, but also environmental (life-cycle assessment) point of view in decision-making process.

\section{Principles of technical and economical evaluation}

\subsection{Technical obstacles, which may have influence on the evaluation of CHP potential}

One of the main technical obstacles, which may influence the CHP potential, is the big amount of heat only boiler plants (HOBs). In most cases the boiler plants are not hydraulically connected into one integrated network (there are no DH networks between two or more boiler plants in one city). A big amount of CHP units results in higher costs of installation and O\&M (operation and maintenance) per $\mathrm{kWh}$, and consequently higher price of generated electricity and heat in CHP systems. Therefore it seems likely that quantity of CHP plants will not be equal to the quantity of boiler plants.

CHP potential could be concentrated by integrating hydraulically simple heat supply networks, but additional investments are necessary for these renovations. Such situation would definitely have negative influence for CHP interest.
By performing the evaluation of additional small scale CHP potential in Lithuanian district heating sector, more than 180 district heating systems were analysed.

\subsection{The main principles of the economical optimiza- tion}

The possibility of integrating small scale CHP into the existing system has been analysed by comparing the reference alternative of conventional centralised electricity production based on CCGT in combination with conventional boilers for district heat production. The following technologies were included:

- Internal combustion engines (Natural gas);

- Gas turbines with heat recovery boilers (Natural gas);

- Steam turbines (Biomass), and

- Biomass gasification systems available after 2010 in the range of $1 \mathrm{MWel}$ to $10 \mathrm{MWel}$ [7].

All technologies have been analysed for an expected lifetime of 20 years [7]. To identify the long-term marginal costs (LTMC) for each of the different CHP technologies, the EnergyPRO operation and investment analysis tool has been used $[3,8]$. LTMC of electricity production from different technologies have been evaluated on the basis that district heating prices should remain the same as, i.e. the alternative costs of heat production in conventional systems. It has been assumed that no profit is expected. The analysis focuses on small scale CHP and, consequently, the six largest DH companies in Lithuania (Vilnius, Kaunas, Klaipeda, Panevėžys, Šiauliai and Alytus) have been excluded. The range of annual DH systems heat production was selected between 50000 MWh and $200000 \mathrm{MWh}$, which is the representative range for the remaining Lithuanian DH sector. An extrapolation has been used for the DH systems, which did not enter the representative range. The database for each of the DH companies' heat production was taken from the Lithuanian District Heating Association [9]. Main assumptions (Table 1) and technical data of the reference case and the different CHP technologies, which are used in the calculations, were taken from [7, 10, 11].

In Fig 1 the results are shown for an annual heat production of $150000 \mathrm{MWh}$.

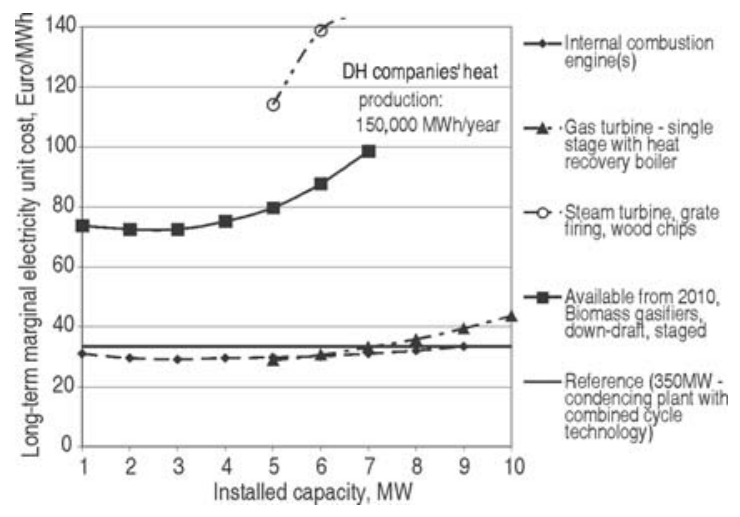

Fig 1. Long-term marginal electricity unit cost 
Table 1. The main assumptions

\begin{tabular}{|c|c|c|c|c|c|}
\hline & $\begin{array}{l}\text { Reference } \\
\text { CCGT }\end{array}$ & $\begin{array}{l}\text { Gas } \\
\text { engines }\end{array}$ & $\begin{array}{c}\text { Gas turbines } \\
\text { with heat } \\
\text { recovery boilers }\end{array}$ & Steam turbines & $\begin{array}{l}\text { Biomass } \\
\text { gasification }\end{array}$ \\
\hline Loan period & \multicolumn{5}{|c|}{20 years } \\
\hline Interest rate & \multicolumn{5}{|c|}{$5 \%$} \\
\hline $\begin{array}{l}\mathrm{CO}_{2} \text { costs } \\
\text { (average in } 20 \text { years period) }\end{array}$ & \multicolumn{5}{|c|}{30 Euro/ $\mathrm{tCO}_{2}$} \\
\hline $\begin{array}{l}\text { Natural gas price, } \\
\text { Euro/1000 natural } \mathrm{m}^{3} \\
\left(9,3 \mathrm{kWh} / \text { natural } \mathrm{m}^{3}\right)\end{array}$ & $\begin{array}{c}110,1 \\
\text { (annual growth } \\
0,9 \% \text { ) }\end{array}$ & \multicolumn{2}{|c|}{$\begin{array}{c}115,8 \\
\text { (annual growth 0,9\%) }\end{array}$} & & \\
\hline $\begin{array}{l}\text { Biomass fuel price, Euro/t } \\
(2,2 \mathrm{kWh} / \mathrm{kg})\end{array}$ & & & & (annual g1 & h $2,6 \%)$ \\
\hline
\end{tabular}

The LTMC of the two CHP technologies based on natural gas is able to compete with the reference within the range of installed capacities up to 7-9 MW.

Meanwhile, the two CHP technologies based on biomass renewable energy sources are much more expensive than the fossil fuel based technologies.

Fig 1 illustrates that the LTMC of electricity production has a minimum. Meanwhile, the minimum is not necessarily representing the optimal investment. In order to identify the business economic optimal situation, the net present value (NPV) of investments in different capacities has been calculated and shown in Fig 2 .

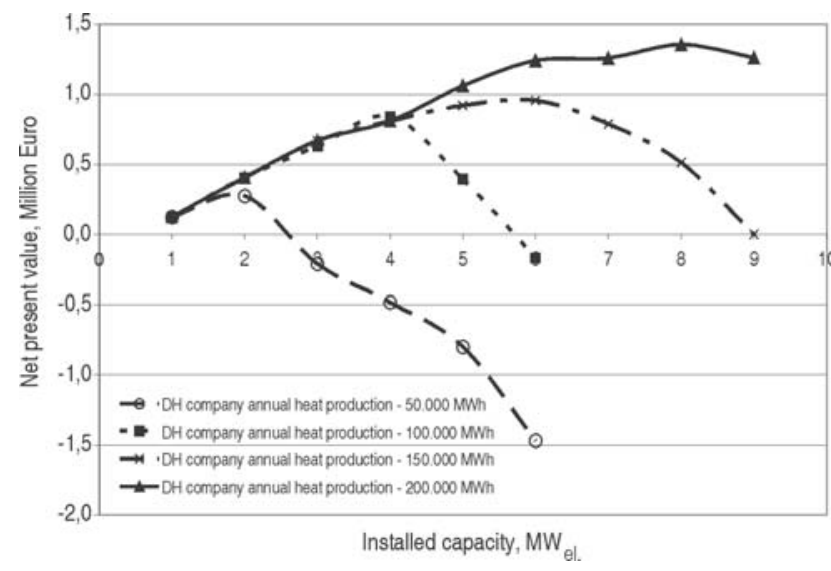

Fig 2. Small-scale CHP business economical capacity optimization

The possible installed capacity optimisation principle of one or more technologies is quite difficult. Usually, there are many possibilities to choose from many combinations, such as: energy generation units quantity, efficiency and technology price combination etc. Fig 2 represents CHP capacity optimisation based on internal combustion engines. The net present value (NPV) shows the gain in a 20 years period. In Fig 2 capacity optimization is done by optimizing only benefits from generating electricity in small scale CHP's instead of conventional generation - reference case. The optimization methodology based on a socio-economic point of view seems to be more difficult. Here, one has to analyse all possible posi- tive and negative effects for different strategies. The $\mathrm{CO}_{2}$ costs and avoided investments into heat boilers renovation were included in this paper as an example of a socioeconomy methodology for optimization of small scale CHP.

\section{The results of the technical and socio-economic optimization}

Based on the methodology described in the previous chapter, optimal small scale CHP capacities in Lithuanian DH sector has been identified from an economic point of view. The analysis compares the following four different situations:

1. Reference electricity price. Compared to the present situation, this case assumes that the Lithuanian authorities have implemented an electricity price regulation securing potential small CHP plants an electricity sales price equal to the LTMC of the reference CCGT production based on natural gas.

2. Reference electricity price plus $\mathrm{CO}_{2}$ payment. In addition to the electricity sales price regulation of situation 1, the small CHP plants pay bonuses that are equal to the $\mathrm{CO}_{2}$ reduction of 30 Euro/ton.

3. Reference electricity price plus $\mathrm{CO}_{2}$ payment plus avoided heat investments. This situation represents the same electricity price regulation and $\mathrm{CO}_{2}$ payment as in situation 2. Additionally, the individual DH company is supposed to be in a situation of needed investments in a new boiler capacities.

4. Only renewable is allowed. Here, small scale CHP's additional capacities are optimised by making the assumption that all DH companies are allowed to produce electricity, only when being based on renewable energy sources and when being feasible compared to the conventional ones.

The fourth case has been included in the analysis, because Lithuania has to increase the share of renewable power generation to a minimum of $7 \%$ by 2010 (currently renewable, mainly hydro, provide approximately $3,2 \%[12,13]$. One way of fulfilling such obligations is to implement the potential of small CHP plants on biomass. 
In the first three situations, electricity, which is based on renewable energy, is produced in DH companies, only when small scale CHP based on renewable fuel is more feasible than both conventional generation and CHP based on natural gas, or when natural gas is not available at the specific location.

The main results of the analysis are shown in Fig 3.

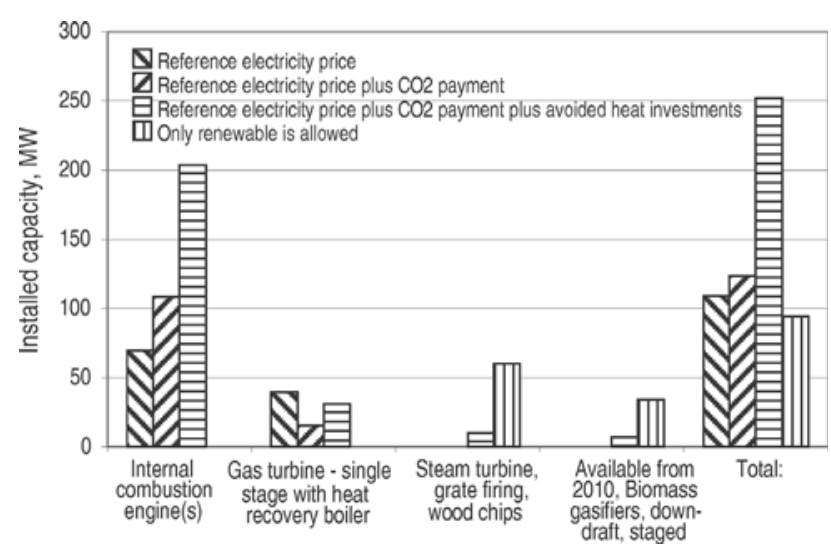

Fig 3. Optimal installed capacities of the different smallscale CHP technologies

Fig 3 shows the economic feasible potential capacity in four situations in total and also divided into four different CHP technologies. As one can see, the potential is very sensitive to the issue of avoided investments in the heat production units. If the DH companies are in a situation of a need for replacement of the existing heat production units, the economic potential becomes more than twice as big as in other situations. The most feasible technology is the internal combustion engine on natural gas. And the only reason, why in some cases, biomass CHP becomes the best alternative, is either the fact that natural gas is not available or as in situation 4 that natural gas is not allowed. The implementation of a $\mathrm{CO}_{2}$ payment influences the potential in a positive direction, however, not very much.

The annual electricity inland consumption in Lithuania currently is around 9,5 TWh [14]. The evaluated potential of small scale CHP varies between 0,5 and 1,4 TWh per year. Consequently, the small scale CHP electricity production could cover up till approx $15 \%$ of the total demand (situation 3 ). The electricity production based on renewable energy could be possibly increase to approx 0,5 TWh per year (situation 4), that is a sensible amount in terms of fulfilling the EU obligation of increasing the share of electricity production from renewable energy to at least $7 \%$.

In relation to the discussion of the replacement of the nuclear power after year 2009, it should be added that the potentials analysed only took into account the existing small DH companies. The potential is even higher if potential new district heating areas are included and substantially higher if the six big existing DH areas are covered as well. Nevertheless, the potential from the small companies alone is substantial and indeed relevant in the discussion of future strategies.
The result in terms of the environmental effects of the different technologies varies along with the fuel savings and whether the fuel is natural gas or biomass. If only renewable is allowed (situation 4), the annual $\mathrm{CO}_{2}$ reduction adds up to approx 190000 tons per year. In three other situations, the $\mathrm{CO}_{2}$ reduction varies between 125000 (situation 1) and 240000 (situation 3) tons per year.

Hence, any investments for producing only heat in DH companies can influence the environmental objectives negatively in the long-term perspective.

\section{The role of investment decision support tools - life cycle assessment}

Sustainable development principles point out that external social and environmental consequences ${ }^{1}$ arising from production systems must be taken into consideration in decision-making at all levels of economic analysis [15]. Encouragingly, over the past few years, environmental costs have, to some extent, begun to be incorporated into industrial activities at both the production and consumption levels. Tighter emission restrictions and taxes, increased environmental fees and other steering measures are helping reallocate a larger portion of socioenvironmental costs to industry in accordance with the polluter-pays-principle (PPP). Likewise, increased environmental awareness amongst consumers and financial institutions has come to mean that a lack of consideration for the environment reflects negatively upon the industry in the form of diminished social acceptance (likely resulting in direct or indirect financial losses), and the willingness of external financial institutions (including the World Bank, and many commercial banks and lending institutions) to lend funds for potentially environmentally harmful investments. Indeed, it is becoming more apparent that, in order to ensure both long-term corporate (in our case - heat and electricity production systems) profitability and environmental performance, it is essential that new investment decisions balance (or at least comprehensively consider) ecological, societal, technical and economic factors simultaneously; this is particularly true for investments in the energy sector, given the manifold social and environmental benefits and costs associated with this complex.

Although traditional financial tools and models for conducting profitability analyses have existed for decades, almost without exception they do not assess the total lifecycle of products, nor do they include hidden or less tangible costs or, for that matter, external or socio-environmental factors. In order for energy companies to make

\footnotetext{
${ }^{1}$ Medical costs for asthma and other respiratory complications attributed to air pollution, income loss in the agricultural sector from pollution-related crop damage and the effects of pesticide-contaminated water on the health of human populations are a few examples of socio-environmental costs which, in the majority of cases, are regarded as "external" to companies.
} 
strategic decisions regarding future investments in sustainable energy services, it is important that decisionsupport frameworks or tools could focus not only upon investment profitability, but also socio-environmental concerns.

\subsection{Life cycle assessment of the typical heating sys- tems in Lithuania}

This chapter presents the preliminary results of a life cycle assessment (LCA) of four typical heating systems in Lithuania. The analysis of production and distribution stages compares the following four alternatives:

1. Decentralised heat production. In this case heat for domestic purposes is produced in many individual small boiler plants operating on natural gas. There, the heat supply network is not required.

2. Conventional district heating system. In this case heat is produced in one big boiler plant. The heat for domestic purposes is supplied through district heating network. Boilers, which are used to produce heat, operate on natural gas. In the calculations it was assumed, that $25 \%$ of the produced heat is $\mathrm{DH}$ network heat losses.

3. CHP based district heating system. In this case heat for domestic purposes is produced in CHP units. In combined heat and power production process, the heat is the main product and the electricity is like a surplus product. CHP energy units operate on natural gas. In the calculation it was assumed, that $25 \%$ of the produced heat is DH network heat losses.

4. CHP based district heating system - renewable. This case is similar to case 2, the only difference being the use of a renewable energy source, wood, instead of natural gas.

As was stated before, electricity is the surplus product for DH system and in the impact assessment the electricity was selected as an avoided product (the electricity generation is avoided in condensing power plant). All calculations were carried out by the PC-tool SimaPRO 6. It is a professional LCA software tool that contains several impact assessment methods and several inventory databases, which can be edited and expanded without limitation.

For the energy generation stage, mostly all data were taken from inventory databases included in SimaPRO 6 (Ecoinvent, ETH-ESU, BUWAL, LCAfood). The data for heat distribution stage are not available in SimaPRO 6, because $\mathrm{DH}$ network geometry, climate conditions of different countries, heat demand/capacity concentrations $(\mathrm{MWh} / \mathrm{MW} / \mathrm{km}), \mathrm{DH}$ water temperature regime etc are case specific and vary with location. These factors are the main reason, why data bases do not contain such type of generalised information.

Based on 5 Lithuanian cities (Gargždai, Rokiškis, Varėna, Šakiai and Ignalina), which could represent Lithuanian regions, necessary data for LCA were analysed.

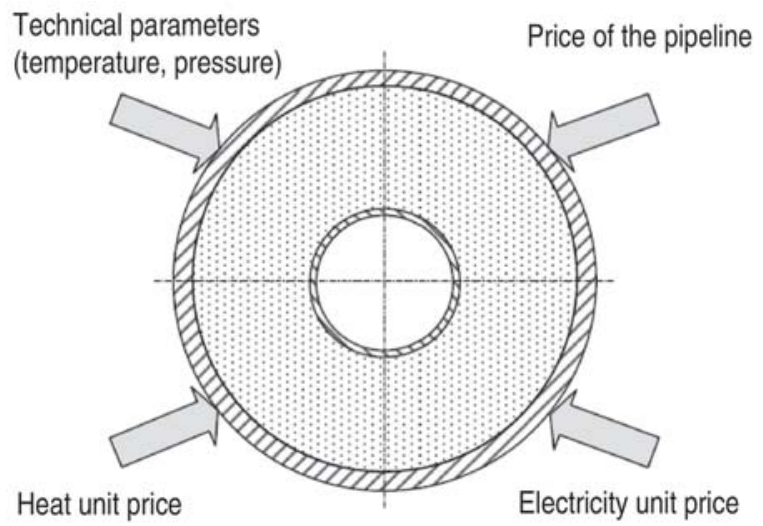

Fig 4. Principles of the DH pipelines diameters optimisation

Existing DH systems in Lithuania were planned and constructed 25-40 years ago. In that time everything was planned with a big margin of reserve, and nowadays pipe diameters are still too big for present heat demand. In some places the overcapacity could be as high as twice the required capacity.

The decision concerning renovation of the DH network should be based not only on life time and technical conditions, but also on expected heat demand in the future (at least 10-20 years). Nevertheless, the renovations of DH networks are unavoidable in the near future.

For all $5 \mathrm{DH}$ networks the diameters optimisation was carried out by minimising the construction and longterm operation costs (heat loss and electricity consumption). The PC-tool "System RORNET" was used for that task [16]. Fig 4 shows the principle of diameters optimisation, where 4 main criteria (technical parameters, pipeline price, electricity and heat unit price) were used.

Having DH networks length distributions by pipeline diameters we can generalise input data for LCA. The main assumptions for general input data are: all materials (steel, polyurethane, HDPE etc) are imported and DH network life time period - 30 years.

Fig 5 shows LCA flows (effect on global warming potential in $\mathrm{kg}$ of $\mathrm{CO}_{2}$ equivalent) for generalised $\mathrm{DH}$ network in Lithuania.

Methods, which were used for LCA of heating systems could be characterised in two groups. The first group is the so-called "midpoint" methods. This group is represented by EDIP 96 (Danish method) and CML (Dutch method developed at the Leiden University). These methods focus on different environmental themes (impact categories) and take a point of departure at the environmental exchange. The second group of methods ("end-point" methods) are used to estimate the harmfulness of various emissions, such as the number of people affected (die or get sick) by particle pollution per year. This is opposite to the previous group of methods, where knowledge of fundamental properties of the substances is used to estimate the potential impacts. The application of two fundamentally different approaches provides 


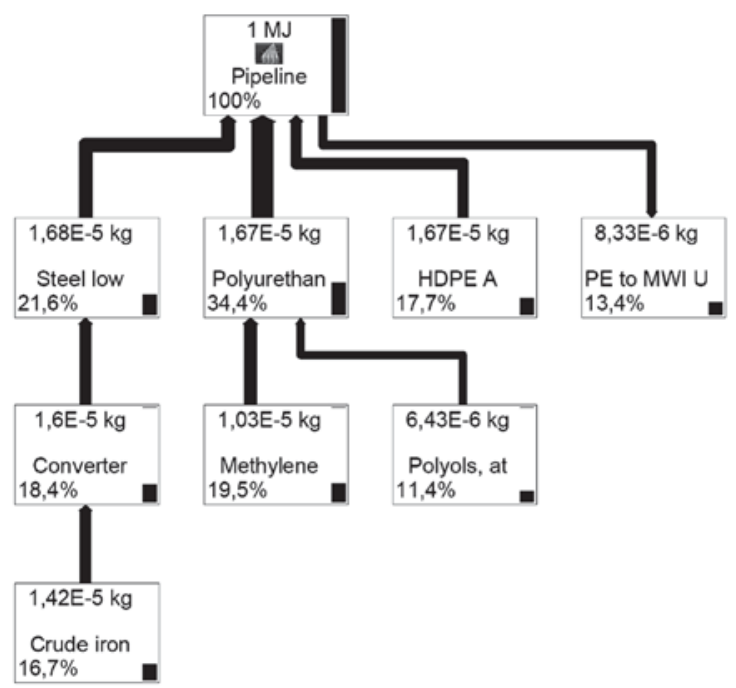

Fig 5. LCA flows of the DH network, cut-off factor: $10 \%$ (heat losses are not included)

a greater certainty in the assessment. The results of all three methods are presented in Fig 6.

Fig 6 shows the first step of impact assessment. This step "translates" the inventory data into environmental impact potentials such as global warming or acidification. Here the impact categories are presented by a category indicator, which varies depending on the LCA method. The second step for LCA, if necessary, could be valuation - normalisation and weighting. Normalisation provides a basis for comparing different types environmental impacts and the weighting step reflects the seriousness of each impact category. In this article only the first and the main step of LCA is presented.

Fig 6 shows that CHP based DH systems are more sustainable in many impact categories than conventional or decentralised DH systems. Nevertheless, conventional DH systems with comparison to decentralised DH systems from LCA point of view are worse in many impact categories.

\section{Conclusions}

The study focuses upon the analysis of methods for the incorporation of technical, economical and environmental considerations into a large-scale investment decision-making in the energy sector.

Results of the analysis for different heating systems show a clear advantage of district heating systems based on CHP instead of conventional energy production. The advantage is from both the socio-economic and the environmental point of view. Some conclusions of this study are summarised.

- If electricity sale prices are provided on the basis of long-term marginal costs of electricity production from CCGT plants, a potential of more than $100 \mathrm{MW}_{\text {el }}$ small-scale CHP becomes economically feasible with a total electricity production of nearly $9 \%$ of the existing demand.

- If a $\mathrm{CO}_{2}$ payment of 30 Euro/ton is included in the calculation, the economical potential of small CHP plants increases slightly, but even so, biomass solutions are still not feasible.

- If small DH companies are in a situation, where they need to invest in new heat production capacities, the small-scale CHP economical potential is raised to $250 \mathrm{MW}_{\mathrm{el}}$ and, in some cases, biomass technologies become feasible if natural gas is not available. In such cases, the economical electricity production will rise to nearly $15 \%$ of the present demand.

- If only biomass is allowed, the economical potential decreases to approx $100 \mathrm{MW}$ or $0,5 \mathrm{TWh}$ per year. It is still a very sensible amount in terms of fulfilling the EU obligation of increasing the share of electricity production from the renewable energy to at least $7 \%$.

- The CHP based DH systems are more sustainable in many impact categories, those conventional or decentralised (individual) heat supply systems.

- The conventional DH systems with comparison to decentralised DH systems from an LCA point of view are environmentally worse in many impact categories.

Based upon the results of the study investigation and analysis, areas for improvement in the current energy sector investment decision-making processes are highlighted, and areas for further research, like incorporation of LCA methods, are recommended.

\section{References}

1. IUCN; UNEP; WWF. The World Conservation Strategy: Living Resource Conservation for Sustainable Development. The Geographical Journal, Vol 148, 1980, p. 363364.

2. European Council. Directive COM/2002/0415 of the European Parliament and the Council on the promotion of cogeneration based on a useful heat demand in the internal energy market. Luxembourg: European Parliament, 2002.

3. Lund, H.; Andersen, A. N. Optimal designs of small CHP plants in a market with fluctuating electricity prices. Energy Conversion and Management, Vol 46, No 6, 2005, p. 893-904.

4. Lithuanian Energy Institute. OPET Cluster. Development of DH/CHP sectors in the CEEC. Phase 1 - District Heating Sector Level, 2003-2004.

5. Seimas of the Republic of Lithuania. The National Energy Strategy, No IX-1130. Vilnius, 2002.

6. Gylys, J. The succession of nuclear energy usage in Lithuania (Atominès energetikos tęstinumo Lietuvoje studija). Kaunas University of Technology, 2003.

7. Danish Energy Authority; Elkraft Systems; Eltra. Technology data for electricity and heat generating plants. 2004. ISBN 87-7844-440-3. 


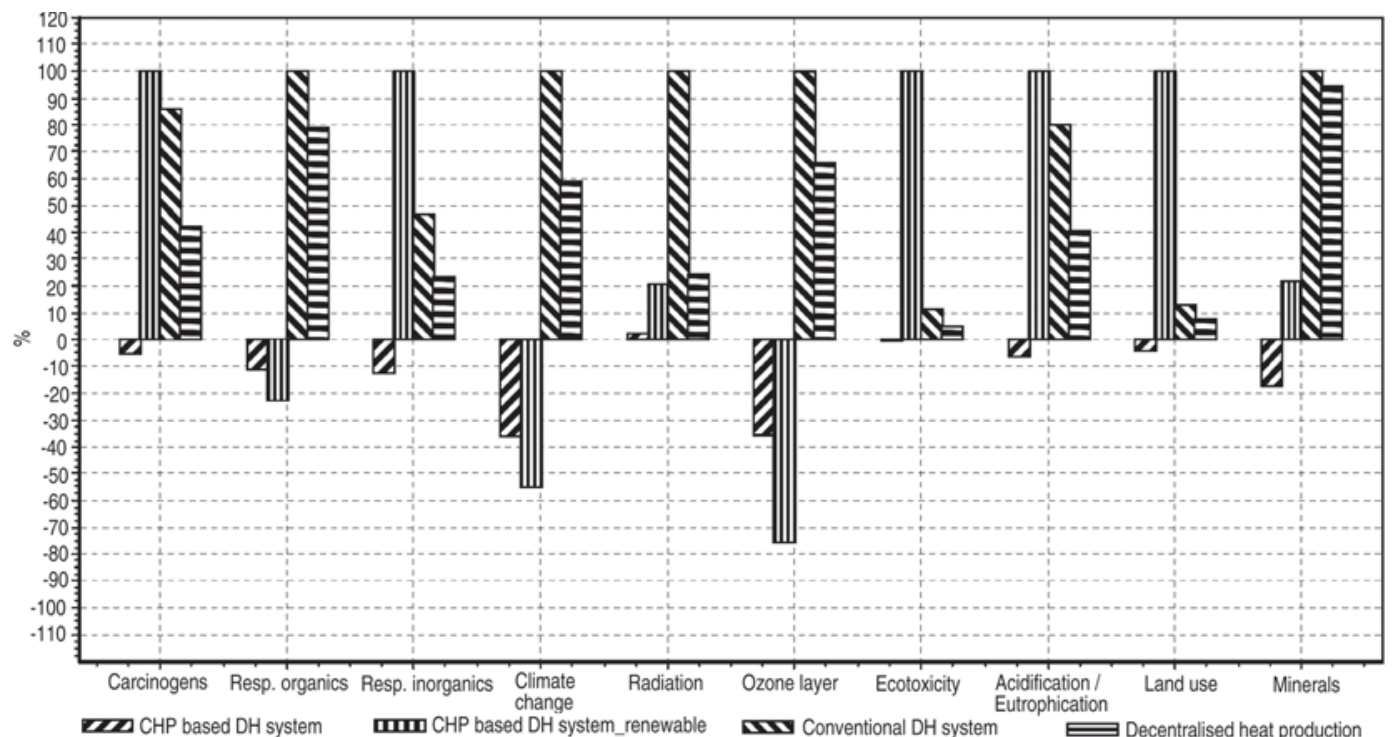

Comparing product stages; Method: Eco-indicator 99(I) V2.1_for DH systems / Europe El 99 V/A/ characterisation
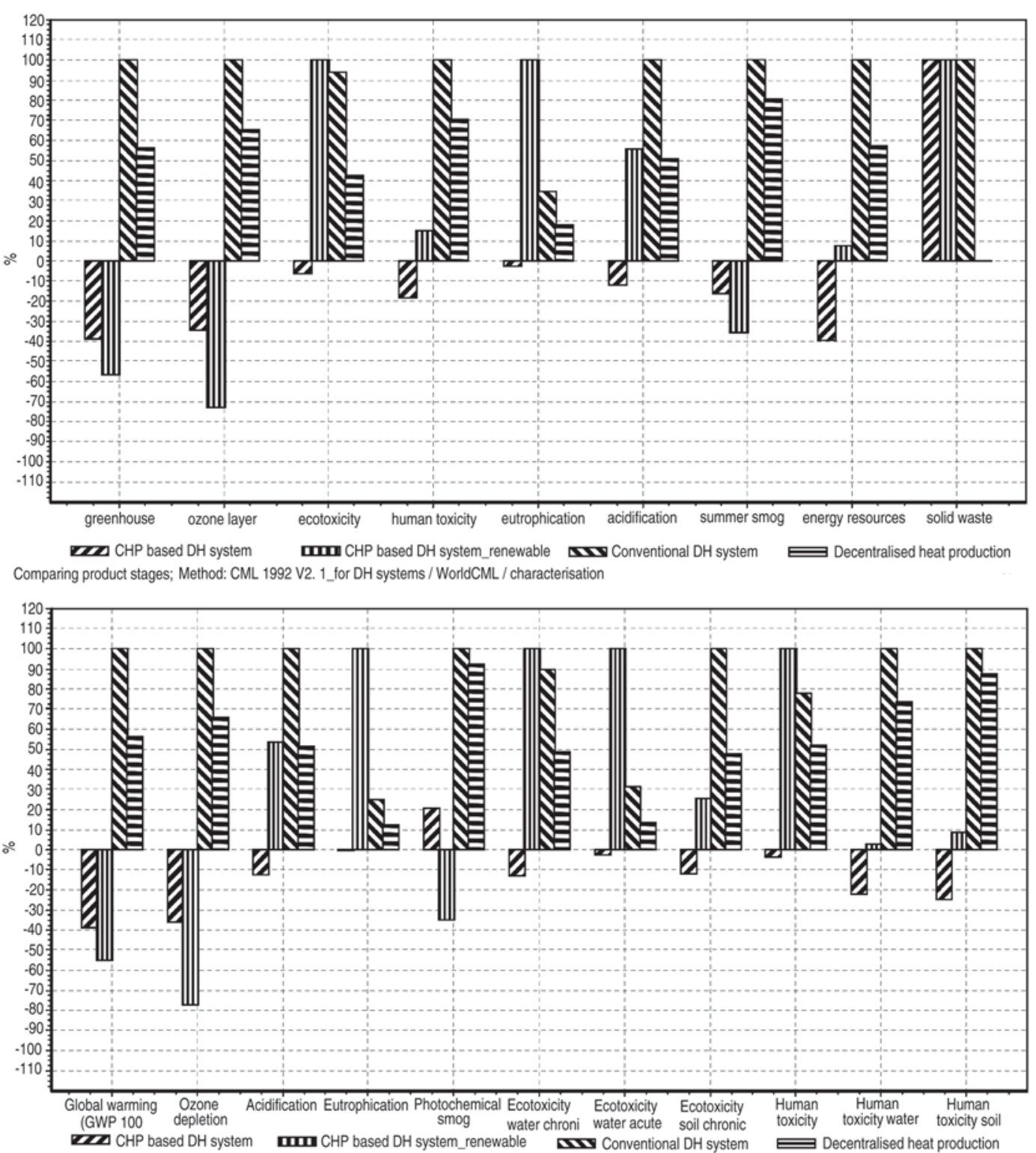
Comparing product stages; Method: EDIP/UMIP 96 V2. 1_for DH systems / EDIP World/DK / characterisation

Fig 6. The results of LCA of typical heating systems in Lithuania 
8. The Independent Institution Energi- og Miløødata. http:// www.emd.dk.

9. Lithuanian District Heating Association (Lietuvos šilumos tiekejų asociacija). http://www.lsta.lt

10. Ministry of Economy of Lithuania. The methodology for estimation of economic impact of disconnection of district heat consumers (Lietuvos Respublikos Ūkio ministerija. Šilumos vartotojų irenginių atjungimo nuo šilumos tiekimo sistemų ekonominio įvertinimo metodika). Vilnius, No 81(1)-3716, 2003.

11. Hendriks, C. Bottom-up Analysis of Emission Reduction Potentials and Costs for Greenhouse Gases in the EU. The Netherlands: ECOFYS Energy and Environment, 2001.

12. Danish Energy Management A/S; Lithuanian Energy Institute. Enhancement of Use of Local and Renewable Energy Sources, Lithuania, 2003.

13. European Council. Directive 2001/77/EC of the European Parliament and the Council of 27 Sept. 2001 on the pro- motion of electricity produced from renewable energy sources in the internal electricity market. Luxembourg: European Parliament, 2001.

14. Ministry of Economy of Lithuanian Republic. Supply security in Lithuanian power market (Lietuvos Respublikos Ūkio ministerija. Tiekimo saugumas Lietuvovos elektros energetikos rinkoje). Monitoring report. Vilnius, 2004.

15. UNCED. Agenda 21: Chapter 8 - Integrating Environment and Development into Decision-Making. New York: United Nations Conference on Environment and Development, 1992.

16. Gudzinskas, J.; Lukoševičius, V.; Rasburskis, N. The thermo-hydraulic analysis of the pipeline systems using the PC tool "SYSTEM RORNET". In: Conference "Heat energetics and technologies" (Šilumos energetika ir technologijos). Kaunas: Technologija, 2001, p. 327-330.

\section{BENDROJI ŠILUMOS IR ELEKTROS ENERGIJOS GAMYBA: SOCIALINĖS EKONOMIKOS IR DARNIOS PLÉTROS ASPEKTAI}

\section{N. Rasburskis, J. Gudzinskas, J. Gylys}

\section{Santrauka}

Ruošiantis uždaryti Ignalinos atominę elektrinę, vienas iš alternatyvių atominès energijos praradimo dalinio kompensavimo būdu yra kogeneracijos plètra centralizuoto šilumos tiekimo sektoriuje. Jau šiandien reikalingos didelès investicijos centralizuoto šilumos tiekimo i̇monėms, siekiančioms atnaujinti šilumos energijos gamybos įrenginius. Taip pat neišvengiamos investicijos Ignalinos atominèje elektrinèje turètai elektros energijos generavimo galiai bent iš dalies kompensuoti. Nepaisant to, kad centralizuoto šilumos tiekimo sektoriuje akivaizdus mažos galios kogeneracijos techninis potencialas, didesnès plètros nèra. Siekiant pokyčių, reikia užtikrinti kogeneracijos tikslingumą ne vien tik socialiniu, bet ir verslo ekonomikos požiūriu. Vienas iš galimų būdų yra viešas elektros ir šilumos rinkos reguliavimas. Darbe pateikti Lietuvos energetinès sistemos analizès rezultatai. Straipsnyje apibendrinami paplitę pavieniai analizès metodai ir plètojami sisteminès analizès principai, galintys susieti techninius, ekonominius ir aplinkosauginius veiksnius. Pabrěžiamas sisteminès analizès svarbumas priimant sprendimus dèl didelių investicijų energetikos sektoriuje. Galutinis šio tyrimo, kurị planuojama baigti $2005 \mathrm{~m}$. pabaigoje, rezultatas - didelio efektyvumo kogeneracijos potencialo i̇vertinimas nacionaliniu mastu ne tik techniniu, bet ir ekonominiu bei aplinkosauginiu požiūriu.

Raktažodžiai: darni plètra, energetikos sektorius, bendra šilumos ir elektros energijos gamyba, centralizuotas šilumos tiekimas, sprendimo prièmimo procesas.

Nerijus RASBURSKIS. MSc, PhD student at the Kaunas University of Technology, Dept of Thermal and Nuclear Energy, Lithuania. Research interests: energy system analysis, feasibility studies, public regulation and technological change. Publications: 12 articles and presentations in Lithuanian and international proceedings (1999-2004).

Jonas GYLYS. Habil Doctor, Professor at the Kaunas University of Technology, Dept of Thermal and Nuclear Energy, Lithuania. Main research interests: hydrodynamics and heat-mass transfer under two-phase (foam) flows, energy systems planning, thermal methods of sewage water treatment, safety problems of nuclear power reactors. More than 200 articles in different journals, books and proceedings.

Juozas GUDZINSKAS. Assoc Professor at the Kaunas University of Technology, Dept of Thermal and Nuclear Energy, Lithuania. Main research interests: energy systems planning, heat savings problems in industry and district heating sector. 